Historic, archived document

Do not assume content reflects current scientific knowledge, policies, or practices. 

NO. 20 .

\section{SPECLHL OFFER}

(1)

\section{Tree Fern Stems,}

\section{ORCHIDS, Etc.}

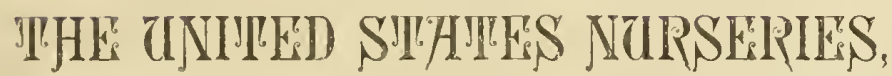

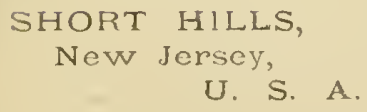

\author{
European Branch, \\ HEXTABLE, \\ SWANLEY, KENT, \\ England.
}




\section{TRET FERN STPMS.}

We have just received from New Zealand, a shipment of over a thousand Tree Fern stems which have arrived in good condition, and which we offer for a short time in the dormant condition at the following prices.

This is a class of plants which deserves more attention than they have thus far received. They are grand decorative plants, their immense arching fronds, as beautiful separately as any fern, giving them an individuality not enjoyed by any other class of plants, not even the Palm. They are distinct and unique for church or parlor decoration, and as they are not as yet in very general use, will be sure to attract attention anywhere.

\section{CULTURAL DIRECTIONS.}

When received the stems should be potted in as small pots as possible and the trunk for about half its length should be wrapped with a layer of moss about an inch thick, loosely held on with wire or cord The application of water to the top should be avoided until the crowns are formed. They require a temperature similar to palms. With proper culture they will all grow, though we cannot guarantee same.

CYATHEA MEDULLARIS. A tall growing tree fern with fronds often ro to $\mathrm{I} 2$ feet long, twice tripinnate, the pinnules serrate in the sterile, pinnately lobed in the fertile fronds; the stems of fronds nearly black, the crown covered with black chaffy hairs, A grand plant for cool treatment.

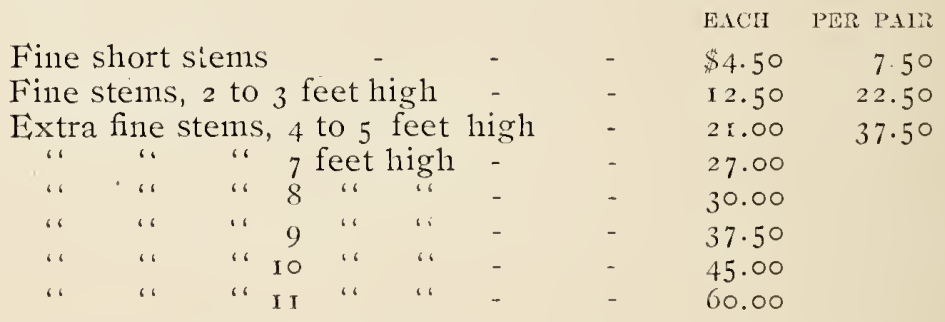

CYATHEA DEALBATA. A fine species with finely divided fronds, almost white beneath.

Fine short stems

Fine stems, 2 to 3 feet high

Extra fine stems, 4 to 5 feet high

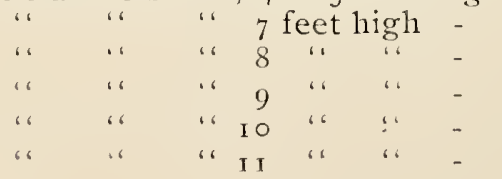

FAC'II PER PAYI

$4.50 \quad 7.50$

$12.50 \quad 22.50$

$21.00 \quad 37.50$

27.00

30.00

37.50

45.00

60.00 


\section{THE UNITED STATES NURSERIES.}

\section{Special Offer of Imported Orchids}

The following additional species have just been received from Soutl Anerica and are offered for a short time at the prices af fixed.

\section{CATTLEYA BICOLOR.}

EAC'H. DOZEN.

Fine plants, 3 bulbs

$\$ 1.00 \$ 10.00$

Very fine plants, 5 bulbs. $\quad$ - $\quad$ - $\quad 1.75$

I 7.50

Strong plants, 7 bulbs. - $\quad$ - $\quad$ - $\quad 2.50$

lixtra strong plants, 9 bulbs

350

CATTLEYA LABIATA WARNERI

Fine pla11ts, 6 bulbs. - $\quad$ - $\quad$ - $\quad$ I.00

Very fine plants, 9 bulbs. - $\quad$ - 200

10.00

Strong plants, I 2 bulbs - 3.00

Very strong plants, I 5 bulbs. - $\quad$ - 4.00

CAT'TLEYA WALKERIANA.

Fine plants, 8 bulbs.

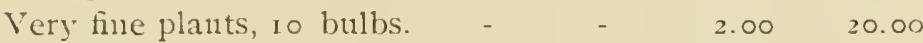

Strong plants, I 5 bulbs. - $\quad 3.00$

Very strong plants, 20 bulbs. - $\quad 5.00$

\section{I,EIIA FIA AVA}

Fine plants, 5 hulbs. - $\quad$ - $\quad$ - $\quad 1.00$

I 0.00

Very fine plants, 9 bulbs.

1. 75

I 7.50

Strong plants, I 2 bulbs.

2. 50

Very strong plants, I 5 bulbs.

3.00

\section{ONCIDIUM MARSHAIIIANUM.}

Fine plants, 5 bulbs.

$2.00 \quad 20.00$

Very fine plants, 7 bulbs $\quad$ - $\quad$ - 3.00

Strong plants,9 bulbs - $\quad$ - $\quad$ - $\quad+4.00$

SOPHRONITIS GRANDIFLORA

Fine plants, 10 lulbs. - $\quad$ - $\quad$ - $\quad \$ 75$

DOZEN.

Very fine plants. $\quad$ - $\quad$ - $\quad$ -

$7 \cdot 50$

Strong plants, $2+$ bulbs.

I 0.00

Very strong plants, 35 bulbs - $\quad$ - 4.00

Specimen plants, 50 bulbs. $\quad$ - $\quad$ - 5.50

ZYGOPETALUM CRINITUM

Fine plants, 6 bulbs.

I. 50 I 500

Very fine plants, 9 bulbs.

2. $50 \quad 25.00$

Strong plants, I 2 bulbs.

4.00

Very strong plants, i 5 bulbs. 
CYATHEA SMITHII (HAMITFIA SMITIII). This fine species has the stems of the large bipinnate fronds covered with rigid scales and the midribs of the fronds are also scaly.

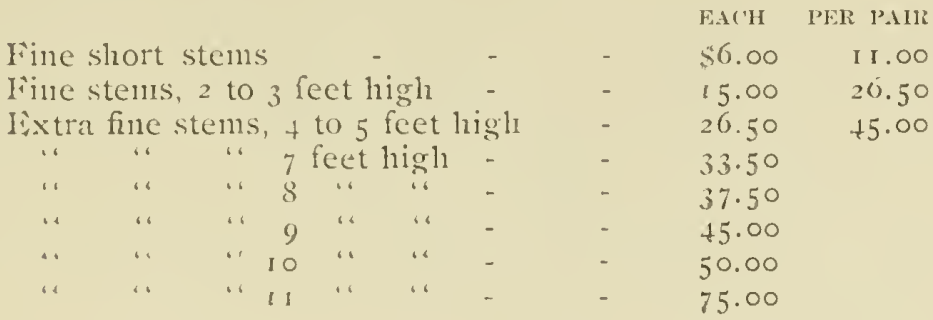

DICKSONIA SQUARROSA. Produces a rather slender trunk hearing a crown of rigid fronds 3 to 6 feet long, standing out at nearly right angles to the trunk.

\begin{tabular}{|c|c|c|c|c|c|c|c|c|c|}
\hline \multirow{2}{*}{\multicolumn{5}{|c|}{$\begin{array}{l}\text { Fine short stemis } \\
\text { Ivine stems, } 2 \text { to } 3 \text { feet livigin }\end{array}$}} & - & - & & 54.50 & \\
\hline & & & & & - & - & & 12.50 & \\
\hline \multirow{2}{*}{ Iixtl } & finc & stenls, & 4 to 5 & feet & high & - & & 21.00 & $37 \cdot 5$ \\
\hline & ' & ." & 7 & "، & $" ،$ & - & & 27.00 & \\
\hline “. & $" “$ & “" & 8 & “" & “" & - & & 30.00 & \\
\hline . & “" & ". & 9 & " & “ & - & & 37.50 & \\
\hline " & $"$ & “ & 10 & $"$ & “" & - & & 45.00 & \\
\hline . & ". & . & II & " & “. & - & ' & 60.00 & \\
\hline
\end{tabular}

LONARIA LANCEOIATA. A low growing species, the stems of the fronds elothed with short brown seales. Fronds 6 to 15 inches long. A pretty species.

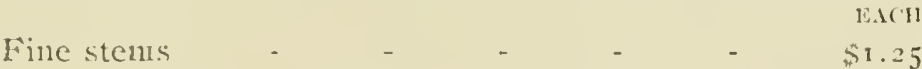

YOMARIA FITVIATIIIS. Stem short and stont, scaly towards the crown: fronds i to 2 feet long. spreading.

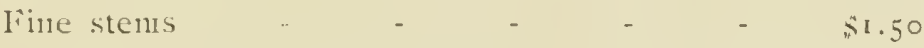

1,OMARIA DISCOLOR. Sten stout, I to 2 feet higli, fronds 1 to 3 feet long, the pinnac numerous, spreading; a fune plant for vases.

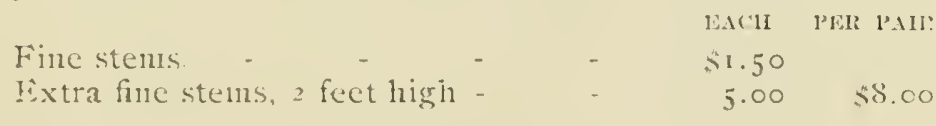

\section{Tobacco Dust.}

The best thing for applying to Chrysanthemums and other plants for keeping down green fly, thrips, red spider and all other plant enemies. Acts also as a fortilizer. P'er lb. 8 ets ; 10 lls. ro ets : 20 liss. \$s.00: 100 lbs. $\$ 400$ 


\section{ORCHIDS.}

\section{CATTLEYA TRIAN E.}

We have just received another consignment of this favorite and most beautiful winter blooming orchid, consisting of . I 60 cases, from our own collector in the Ibague district. They have arrived in first-class condition and are offered as follows:

\begin{tabular}{|c|c|c|}
\hline & $\mathrm{EACH}$ & DOZED \\
\hline Good plants, 3 to 5 bulbs - & $\$ .75$ & $7 \cdot 5$ \\
\hline ine plants, 6 to 8 bulbs & 1.00 & 10.00 \\
\hline ery fine plants, 9 to 12 bulbs & $x .5^{\circ}$ & I 5.00 \\
\hline ong plants, i 5 to i 8 bulbs - & 2.00 & 20.00 \\
\hline xtra strong plants, 20 to 25 bulbs & 3.00 & 30.00 \\
\hline ecimen plants, 30 to 35 bulbs - & 5.00 & \\
\hline to 40 bull & $7 \cdot 50$ & \\
\hline specimen & 10.00 & \\
\hline
\end{tabular}

\section{CATTLEYA SPECIOSISSIMA.}

A fine consignment of this desirable Cattleya has just been received from our own collector in Venezuela, and are offered as follows :

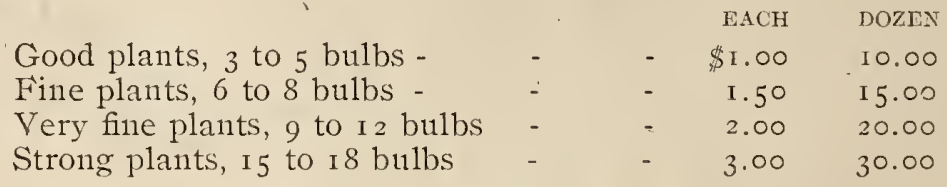

\section{CATTLEYA MOSSIE.}

Fine plants in healthy state, just received from our own collector are offered as follows :

\begin{tabular}{|c|c|c|c|c|}
\hline & & & EACH & DOZEN \\
\hline Good plants, 3 to 5 bulbs - & - & - & \$.75 & $\$ 7 \cdot 5 \circ$ \\
\hline Fine plants, 6 to 8 bulbs & - & - & 1.00 & I 0.00 \\
\hline Very fine plants, 9 to i 2 bulbs & - & - & I. 50 & 1500 \\
\hline Strong plants, i 5 to i 8 bulbs & - & - & 2.00 & 20.00 \\
\hline Extra strong plants, 20 to 25 buil & & - & 3.00 & 30.00 \\
\hline pecimen plants, 30 to 35 bulbs & & - & 5.00 & \\
\hline
\end{tabular}

\section{CYPRIPEDIUM LONGIFOLIUM.}

A recent consignment of this desirable species is offered as follows :

$\begin{array}{lllrr}\text { Fine plants, I growth } & & & \text { EACH } & \text { DOZEN } \\ \text { Strong plants, } 2 \text { growths - } & - & - & \$ .75 & \$ 7.50 \\ \text { Fine and strong plants, 3 growths } & - & 3.00 & 20.00\end{array}$

TRICHOPILIA SUAVIS.

$A$ recent importation of healthy plants of this desirable Orchid are offered as follows:

Good plants, 2 to 4 bulbs

Fine plants, 5 to 7 bulbs

EACH DOZEN

$\$ .75 \$ 7.50$

1. $50 \quad 15.00$ 